\title{
Pinus sylvestris Breeding for Resistance against Natural Infection of the Fungus Heterobasidion annosum
}

\author{
Raitis Rieksts-Riekstinšs ${ }^{1}$, Pauls Zeltin̦šs ${ }^{1} * \mathbb{0}$, Virgilijus Baliuckas ${ }^{2}$, Lauma Brūna ${ }^{1}$, \\ Astra Zalıuma ${ }^{1}$ and Rolands Kāpostinšs ${ }^{1}$ \\ 1 Latvian State Forest Research Institute Silava, 111 Rigas street, LV-2169 Salaspils, Latvia; \\ raitis.riekstins@silava.lv (R.R.-R.); lauma.bruna@silava.lv (L.B.); astra.zaluma@silava.lv (A.Z.); \\ rolands.kapostins@silava.lv (R.K.) \\ 2 Forest Institute, Lithuanian Centre for Agriculture and Forestry, Department of Forest Tree Genetics and \\ Breeding, Liepu St. 1, Girionys, LT-53101 Kaunas distr., Lithuania; virgilijus.baliuckas@mi.lt \\ * Correspondence: pauls.zeltins@silava.lv
}

Received: 28 November 2019; Accepted: 19 December 2019; Published: 22 December 2019

check for updates

\begin{abstract}
Increasing resistance against biotic and abiotic factors is an important goal of forest tree breeding. The aim of the present study was to develop a root rot resistance index for Scots pine breeding and evaluate its effectiveness. The productivity, branch diameter, branchiness, stem straightness, spike knots, and damage from natural infection of root rot in 154 Scots pine open-pollinated families from Latvia were evaluated through a progeny field trial at the age of 38 years. Trees with decline symptoms were sampled for fungal isolations. Based on this information and kriging estimates of root rot, 35 affected areas (average size: $108 \mathrm{~m}^{2}$; total 28\% from the 1.5 ha trial) were delineated. Resistance index of a single tree was formed based on family adjusted proportion of live to infected trees and distance to the center of affected area. Heritability for resistance to root rot based on the value of this index, was high (0.37) and comparable to indices of growth traits. Correlations of family breeding estimates between resistance to root rot and the other traits were not significant, except for a weak, yet significant, positive correlation with diameter at breast height and branch diameter. Selection index including only growth traits (height and stem volume) had a negligible effect on damage by root rot. We detected a maximum genetic gain in resistance index of $33.7 \%$ when incorporating it into the selection index with positive gains for growth traits (6.5-11.0\%). Two-stage selection with prior selection of the most resistant families was not superior to the use of selection index with only rot resistance included. Overall; rot resistance index appeared to be an effective tool in tree breeding for the selection of more resistant families, using the existing trials with natural (uncontrolled) infection
\end{abstract}

Keywords: selection index; root rot; growth; genetic gain; two-stage selection; heritability

\section{Introduction}

Scots pine (Pinus sylvestris L.) is one of the most economically important tree species in the Baltic States and Scandinavia. In this region, it is regenerated primarily by planting, and most of all the plant material is a result of tree breeding; seeds for plant production are collected from seed orchards. Thus, it is both relatively straightforward as well as important to improve a particular trait in significant portion of Scots pine stands. Scots pine breeding primarily had been focused on achieving gain in traits related to productivity (height, diameter, volume production), and frost hardiness in the northern part of the region. In these traits, considerable gain has been achieved [1]. However, little has been done in resistance breeding at practically applicable scale; the most prominent activities include selection 
of resistance against needle cast (Lophodermium spp.) across the region and against pine blister rust (Cronartium flaccidum and Peridermium pini) in northern Sweden [2-4].

Two species of the fungus genus Heterobasidion are found in Northern Europe: H. annosum (Fr.) Bref. and H. parviporum Niemelä and Korhonen. Scots pine is highly susceptible to root rot caused by H. annosum [5]. The biology of the pathogen has been studied intensively [6], nevertheless host genotypes with total resistance to root rot have not been observed for Scots pine or Norway spruce [7]. Considerable effort has been made to study genetic control of root-rot resistance in Norway spruce [8,9]. However, in context of changing climate, Scots pine must also be given a high priority. Genetic control of resistance has been previously detected in P. sylvestris [10], and clones with apparently varying resistance have been detected in seed orchards [11] and among seedlings [12]. At the genetic level, a recent study about terpenoids associated with $P$. sylvestris defensive mechanisms against $H$. annosum has indicated higher expression of genes encoding certain terpenoid compounds, thus showing potential to identify susceptibility of trees based on inherent genetic and chemical properties [13]. Moreover, copy number variation polymorphism had been detected for a gene encoding a thaumatin-like protein, involved in antimicrobial activity against 12 fungal species. As increased gene copy number can lead to increased gene product amounts in cells, candidate of more resistant genotypes can be detected [14].

Previous studies have recommended planting the most resistant genotypes, though it remains difficult to perform the mass testing of these genotypes for their selection and use in practical breeding. One of the methods-genetic screening-can be biased, while controlled inoculation is expensive at large scale. Besides reported results from inoculation experiments allow to evaluate resistance against pathogen spread from already infected trees [15-17], but not the ability of trees to avoid infection. It would be beneficial (saving time and resources) to use existing trials with naturally occurring infection. Heterobasidion spp. has a mixed infection biology: (i) Primary infections via airborne spores can originate form freshly exposed sapwood, (ii) secondary infection via vegetative growth of mycelium to neighboring trees. Other ways-e.g., via browsing damage-are very unlike for Scots pine [5].

Regarding substantial economic losses due to dieback caused by the pathogens, inclusion of resistance to H. annosum in Scots pine breeding strategies should be considered. Resistance to disease commonly exhibits strong gains and lacks undesirable correlations with other priority traits, hence the common integration of this strategy in tree breeding programs [18]. Incorporation of root rot resistance into the selection criteria — e.g., index selection [19]—alongside genetic gains of economically important traits, such as tree height and stem volume, may represent a viable strategy to increase net genetic improvement [20]. For Norway spruce, early selection for resistance to H. parviporum observed not to have negative effect on growth and wood quality later [9]. However, an additional trait in the selection criteria reduces the gains on already included traits [18]. Thus, a reasonable measurement of resistance against root rot-one that preferably possesses substantial genetic variance and would provide practically important genetic gains-is required. As such, the aim of the present study is to construct a root rot resistance index for Scots pine and evaluate its effectiveness.

\section{Materials and Methods}

\subsection{Studied Trial and Measurements}

The assessed Scots pine progeny trial consisted of 154 open-pollinated families from 13 Latvian populations. The trial site was located in eastern Latvia $\left(56^{\circ} 40^{\prime} \mathrm{N}, 25^{\circ} 57^{\prime} \mathrm{E}\right)$, in flat terrain, ca. $110 \mathrm{~m}$ above sea level, and was characterized by a rather continental climate [21]. Mean annual temperature was $+6.0^{\circ} \mathrm{C}$, and mean monthly temperature ranged from $-6.4^{\circ} \mathrm{C}$ to $+17.1^{\circ} \mathrm{C}$ in February and July, respectively. Mean annual precipitation was ca. $700 \mathrm{~mm}$ [22]. The trial was established in 1979 using one-year-old bare-rooted seedlings with an initial spacing of $2 \times 1 \mathrm{~m}$. The site corresponded to the Cladinoso-callunosa forest type according to Latvian forest typology [23]. A randomized block design was used with eight blocks and eight trees row-plot. In total, 4695 trees were available for analysis. 
No thinning or other silvicultural measures had been carried out during the trial, thus the only source of natural infection of $H$. annosum had been old Scots pine stumps remaining from previous stand (harvested at mature age).

Evaluations were performed after 38 years of growth, and height $(\mathrm{H})$, diameter at breast height $(\mathrm{DBH})$, and diameter of the thickest branch until the stem height of $2 \mathrm{~m}(\mathrm{BrD})$ was measured for each tree. Stem volume (StVol) was calculated according to Liepa [24], and the occurrence of spike knots $(\mathrm{SpKn})$ was recorded as a binary variable $(1=$ present, $0=$ absent $)$. Arbitrary scores using a three-point scale of stem straightness (StStr) and branchiness (Branch) were assessed ( $1=$ straight stem/relatively thin branches, 3 = crooked stem/relatively thick branches).

Regarding their potential resistance to $H$. annosum, trees were allocated in three categories: (1) Asymptomatic trees; (2) symptomatic trees based on crown conditions and fruit bodies on root collar; and (3) dead trees. To evaluate the proportion of actually infected trees, all trees from the Category 2 and 3 (altogether 421) were cut. Wood samples (cross sections) were collected from those stumps. Asexual sporulation (conidiophores) was used to confirm the presence of the pathogen. Isolation and identification of Heterobasidion from all samples was attempted according to previous work [17].

Provided data were analyzed using the procedures VARIOGRAM and KRIGE2D in SAS 9.3 software (SAS Institute, Cary, NC, USA) [25] to define affected areas of root rot. Kriging was used as a geostatistical interpolation method to estimate unknown value for trees considering both the distance and the degree of variation between known data points when estimating values in unknown areas. A kriged estimate of root rot infection for a tree was a weighted linear combination of the known sample values (infected trees with registered $H$. annosum) around the point to be estimated as an optimal and unbiased estimate. A semivariogram of the data was constructed to weight nearby sample points when interpolating [26]. Based on kriged estimates larger than zero, presumably infected plots were delineated.

\subsection{Data Analysis}

Within the established affected area, root rot resistance index (RotResist) was formed:

$$
\text { RotResist }=\text { IndDist }+ \text { IndRot }+ \text { IndRotFam }
$$

where IndDist is inverted distance from the tree to the plot center (average plot radius minus tree distance to the plot center), IndRot is the ratio of number of trees in the plot to number of killed by $H$. annosum trees in the plot, and IndRotFam is the ratio of number of certain families' trees in the parcel to number of trees in the certain parcel that are included into a delineated root-rot plot. The index IndDist is inverted distance, because the larger value should indicate higher resistance for a living tree closer to the plot center. Similarly, IndRot and IndRotFam are inverted proportions of killed trees by root rot in the plot and trees per family parcel that is included in the plot, respectively, by this means securing larger resistance index values for alive trees under higher risk conditions.

Variance components for variables were estimated using the SAS Mixed (PROC MIX) and Generalized Linear Mixed (PROC GLIMMIX) procedures with the restricted maximum likelihood approach [27,28]; and standard error values were calculated using Dickerson's approximation [29]. Root rot variance components for heritability calculations were estimated using data only from affected areas. The following model was used:

$$
y_{i j k}=\mu+B_{i}+F_{j}+B F_{i j}+\varepsilon_{i j k}
$$

where $y_{i j k}$ is the observation on the $k$ th tree from the $j$ th family in the $i$ th block; $\mu$ is the overall mean; $B_{i}$ is the fixed effect of the $i$ th block; $F_{j}$ and $B F_{i j}$ are the random effects of the $j$ th family and interaction of the $i$ th block and the $j$ th family, respectively, and $\varepsilon_{i j k}$ is the random residual effect. For estimating the variance components of the root rot resistance index, block effect was substituted in the model 
by plot effect since resistance index was calculated only in established affected areas that represented more homogenous growing conditions than blocks.

Estimates of narrow-sense heritability $\left(h^{2}\right)$ were calculated as follows:

$$
h^{2}=\frac{4 \times \hat{\sigma}_{f}^{2}}{\hat{\sigma}_{f}^{2}+\hat{\sigma}_{f b}^{2}+\hat{\sigma}_{\varepsilon}^{2}},
$$

where $h^{2}$ is narrow-sense heritability and $\hat{\sigma}_{f}^{2}, \hat{\sigma}_{f b^{\prime}}^{2}$ and $\hat{\sigma}_{\varepsilon}^{2}$ are the estimated variance components of the family, family $\times$ block interaction, and the residual, respectively.

Family breeding values were estimated as double general combining ability values [19] using a best linear unbiased predictors (BLUP) procedure in SAS [25]. For binary traits, predicted probabilities were estimated by applying the inverse of the link function [27]. We applied different alternative criteria for the selection. However, all of the alternative strategies had independent culling levels [18] set as a first step. Namely, trees with breeding values for studied stem quality traits no more than $10 \%$ lower than the trial mean were selected. In combination with the culling, further criteria were applied (Figure 1).

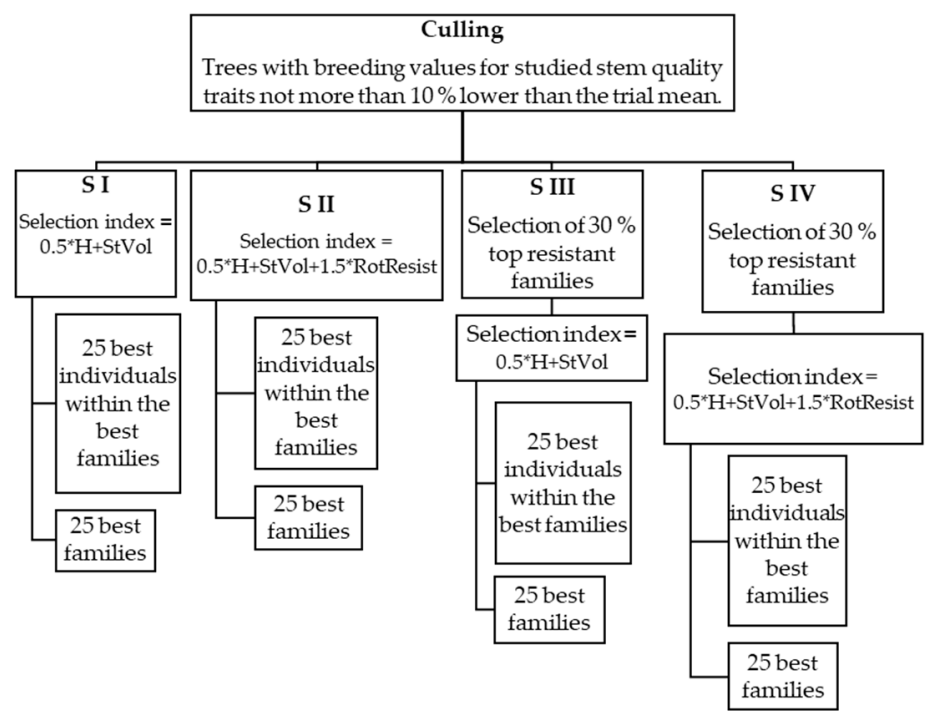

Figure 1. Scheme of the different selection criteria applied. Abbreviations: H—tree height; StVol—stem volume; RotResist—root rot resistance index.

First, standard Scots pine breeding methodology in Latvia was applied for a selection of the best performing families and trees [30]. Tree height and volume were used (selection index $=0.5 \times($ height breeding estimate $)+1.0 \times$ (stem volume breeding estimate) $)$. We selected the 25 best trees within the 25 top-ranked families (one from each selected family) and weighted each tree by the number (proportion) of ramets for a seed orchard. None of the families was represented by less than 10-15 progeny nor were any of the best families' clones allowed to comprise more than $10 \%$ of the total number of ramets. Second, root rot resistance index was included separately to the selection index formula by weighting it equally to the productivity traits (Selection index $=0.5 \times$ (height breeding estimate) $+1.0 \times($ stem volume breeding estimate) $+1.5 \times$ (root rot resistance index breeding estimate) $)$. The third and the fourth approaches were similar to the aforementioned approaches but involved applying two-stage selection (tandem selection in the same breeding cycle) [18] with an initial selection of the 30\% most resistant families. Thereafter, the four selection criteria were labelled as S I, S II, S III, and S IV (Figure 1).

\section{Results}

For 149 trees, 28 different $H$. annosum genotypes were registered over a total area of 1.55 ha, and 35 affected areas of root rot obtained. The mean affected area was $108 \mathrm{~m}^{2}$. Distance between areas ranged from 2 to $74 \mathrm{~m}$, and in total they covered $27.5 \%$ of the trial area. 
Narrow-sense heritability for RotResist was high (0.37, cf. Falconer and Mackay [19]) and comparable to the heritability of productivity traits, which were moderate to high $(0.25-0.45)$. Stem quality traits, such as stem straightness, branchiness, branch diameter, and the occurrence of spike knots, had low (0.02-0.13) heritability estimates (Table 1). Correlations of family breeding values of RotResist and the remaining analyzed variables were not significant, with the exception of a weak (cf. Evans [31]), positive correlation with DBH $(r=0.16, p=0.05)$, StVol $(r=0.19, p=0.02)$, and BrD $(r=0.28, p<0.01)$. Productivity traits $(\mathrm{H}, \mathrm{DBH}$ and $\mathrm{StVol})$ showed very high correlation $(r \geq 0.88$, $p<0.01)$ among themselves and moderate to high $(0.51<r<0.65, p<0.01)$ correlation with $\mathrm{BrD}$ (Table 2).

Table 1. Mean, minimum (Min), and maximum (Max) values and narrow-sense heritability indices of the studied traits.

\begin{tabular}{ccccc}
\hline Trait & $\begin{array}{c}\text { Mean } \pm \text { Standard } \\
\text { Deviation }\end{array}$ & Min & Max & $\begin{array}{c}\text { Narrow-Sense Heritability } \\
\boldsymbol{h}^{\mathbf{2}} \pm \text { standard Error }\end{array}$ \\
\hline Height $(\mathrm{m})$ & $9.7 \pm 2.42$ & 1.9 & 16.1 & $0.45 \pm 0.094$ \\
Diameter at breast height $(\mathrm{cm})$ & $10.3 \pm 4.06$ & 1.0 & 23.0 & $0.25 \pm 0.069$ \\
Stem volume $\left(\mathrm{dm}^{3}\right)$ & $55.6 \pm 43.39$ & 0.3 & 274.9 & $0.28 \pm 0.072$ \\
Branch diameter $(\mathrm{cm})$ & $1.5 \pm 0.43$ & 0.3 & 4.5 & $0.13 \pm 0.053$ \\
Branchiness (score) & 1.4 & 1.0 & 3.0 & $0.10 \pm 0.048$ \\
Spike knots $(\%$ of trees) & 21.8 & - & - & $0.03 \pm 0.077$ \\
Stem straightness (score) & 1.2 & 1.0 & 3.0 & $0.02 \pm 0.042$ \\
Root rot resistance index & $0.78 \pm 1.34$ & -1.9 & 8.6 & $0.37 \pm 0.220$ \\
\hline
\end{tabular}

Table 2. Family mean breeding value correlations (significant correlations with $p \leq 0.05$ in bold) in the upper diagonal part and their $p$-values in the lower diagonal part. Abbreviations: H-height; $\mathrm{DBH}$ —diameter at breast height; StVol—stem volume; BrD—branch diameter; Branch—branchiness; StStr—stem straightness; SpKn—spike knots; RotResist—root rot resistance index.

\begin{tabular}{ccccccccc}
\hline & $\mathbf{H}$ & DBH & StVol & BrD & Branch & StStr & SpKn & RotResist \\
\hline H & 1 & $\mathbf{0 . 8 9}$ & $\mathbf{0 . 8 8}$ & $\mathbf{0 . 5 1}$ & -0.10 & $\mathbf{0 . 3 9}$ & $\mathbf{- 0 . 2 7}$ & 0.15 \\
DBH & $<0.01$ & 1 & $\mathbf{0 . 9 8}$ & $\mathbf{0 . 6 5}$ & $\mathbf{- 0 . 3 4}$ & $\mathbf{0 . 3 1}$ & $\mathbf{- 0 . 2 5}$ & $\mathbf{0 . 1 6}$ \\
Vol & $<0.01$ & $<0.01$ & 1 & $\mathbf{0 . 6 2}$ & $\mathbf{- 0 . 3 4}$ & $\mathbf{0 . 2 6}$ & $\mathbf{- 0 . 2 5}$ & $\mathbf{0 . 1 9}$ \\
BrD & $<0.01$ & $<0.01$ & $<0.01$ & 1 & $\mathbf{- 0 . 5 8}$ & 0.04 & -0.13 & $\mathbf{0 . 2 8}$ \\
Branch & 0.19 & $<0.01$ & $<0.01$ & $<0.01$ & 1 & 0.15 & 0.02 & -0.15 \\
StStr & $<0.01$ & $<0.01$ & $<0.01$ & 0.59 & 0.06 & 1 & $\mathbf{- 0 . 2 4}$ & -0.03 \\
SpKn & $<0.01$ & $<0.01$ & $<0.01$ & 0.11 & 0.76 & $<0.01$ & 1 & 0.07 \\
RotResist & 0.06 & 0.05 & 0.02 & $<0.01$ & 0.06 & 0.71 & 0.38 & 1 \\
\hline
\end{tabular}

The applied different selection criteria highlighted a varying response to selection (Table 3). Selection index considering only $\mathrm{H}$ and StVol (S I) would not notably alter damage by root rot via selection of the 25 best individuals from each family (genetic gain $2.3 \%$ ) or from the 25 top families (genetic gain $4.9 \%$ ). If the tree root rot resistance index was included to the selection index formula with equal weighting-to-productivity traits (S II), then the observed increase in root rot resistance comprised $30.0 \%$ of cases where individuals were selected and $33.7 \%$ when top families were selected. Genetic gain estimates for $\mathrm{H}, \mathrm{DBH}$ and $\mathrm{StVol}$ were reduced considerably, but the other traits were quite robust with the inclusion of RotResist to the selection index. The two-stage (tandem) selection process allowed increased genetic gain for root resistance index when applying both S III and S IV. Initial selection of the top $30 \%$ of resistant families resulted in an improved resistance index among $15.4 \%$ (the best individuals) and $27.0 \%$ (the best families) when applying S III. The inclusion of resistance in the selection index in S IV increased the genetic gain for rot resistance to 27.7 and $35.2 \%$ for the individuals and the families, respectively. Generally, when selecting the best 25 families instead of the best 25 individuals from each family, the estimated genetic gains for $\mathrm{H}, \mathrm{DBH}$, and StVol were less sensitive to the inclusion of resistance in the selection index (Table 3). 
Table 3. Estimated genetic gain for the studied variables using different selection criteria: S I—selection index with only height (H) and stem volume (StVol) included; S II-selection index with root rot resistance index (RotResist) included; S III-two-stage selection with the selection of $30 \%$ of individuals from families with the greatest resistance prior to the application of conventional selection index; S IV-two-stage selection with the selection of $30 \%$ of families with the greatest resistance prior to the application of selection index with RotResist included. For all criteria, the selection of the 25 best individuals within the best families or selection of the 25 best families regarding the selection index are applied.

\begin{tabular}{|c|c|c|c|c|c|c|c|c|c|}
\hline \multirow{2}{*}{ Selection Criterion } & & \multicolumn{8}{|c|}{ Genetic Gain (\%) } \\
\hline & & Height & $\begin{array}{c}\text { Diameter at } \\
\text { Breast Height }\end{array}$ & $\begin{array}{c}\text { Branch } \\
\text { Diameter }\end{array}$ & Branchiness & $\begin{array}{c}\text { Stem } \\
\text { Straightness }\end{array}$ & $\begin{array}{l}\text { Spike } \\
\text { Knots }\end{array}$ & $\begin{array}{c}\text { Stem } \\
\text { Volume }\end{array}$ & $\begin{array}{c}\text { Root Rot } \\
\text { Resistance Index }\end{array}$ \\
\hline \multirow{2}{*}{ S I $(0.5 \times \mathrm{H}+\mathrm{StVol})$} & 25 best individuals & 16.5 & 13.2 & 3.0 & -0.6 & 0.1 & -1.1 & 44.3 & 2.3 \\
\hline & 25 best families & 14.5 & 17.8 & 6.3 & -2.4 & 0.2 & -15.4 & 50.6 & 4.9 \\
\hline \multirow{2}{*}{ S II $\left(0.5 \times \mathrm{H}+\mathrm{StVol}+1.5^{*}\right.$ RotResist $)$} & 25 best individuals & 6.5 & 4.7 & 1.6 & 0.3 & 0.1 & -1.6 & 10.9 & 30.0 \\
\hline & 25 best families & 10.4 & 13.5 & 6.0 & -2.4 & 0.0 & -0.5 & 38.1 & 33.7 \\
\hline \multirow{2}{*}{ S III (Two-stage selection/0.5 × H + StVol) } & 25 best individuals & 16.4 & 12.5 & 2.8 & -0.2 & 0.0 & -1.0 & 41.0 & 15.4 \\
\hline & 25 best families & 11.5 & 14.3 & 4.8 & -2.4 & 0.1 & -2.3 & 39.7 & 27.0 \\
\hline \multirow{2}{*}{$\begin{array}{c}\text { S IV (Two-stage selection } / 0.5 \times \mathrm{H}+\mathrm{StVol}+ \\
1.5 \times \text { RotResist })\end{array}$} & 25 best individuals & 6.5 & 4.6 & 1.7 & 0.2 & 0.1 & -1.4 & 10.7 & 27.7 \\
\hline & 25 best families & 9.5 & 12.8 & 5.5 & -2.3 & 0.0 & 0.6 & 35.7 & 35.2 \\
\hline
\end{tabular}




\section{Discussion}

\subsection{Genetic Parameters}

Although there are no conifer species with genetically determined total resistance against the pathogen Heterobasidion spp. [6,7], estimated high heritability of resistance index (Table 1) suggests existing variation in the susceptibility of Scots pine to this fungus being strongly genetically controlled. Genetic control has been commonly reported in the resistance of Norway spruce P. abies to Heterobasidion spp. [8,15,32-37], moreover the genetic component in the resistance of Scots pine has also been previously detected [10]. The narrow-sense heritability $\left(h^{2}=0.37\right)$ for RotResist was similar or higher to the indices estimated for $H$. parviporum lesion length in the phloem $\left(0.17<h^{2}<0.33\right)$ and fungal growth in sapwood $\left(h^{2}=0.42\right)$ in Norway spruce open-pollinated progenies [9,37]. Also, for Norway spruce clones, moderate broad-sense heritability $\left(H^{2}=0.21\right)$ has been estimated for lesion length [15]. Swedjemark and Karlsson [33] reported moderate broad-sense heritability $\left(H^{2}=0.28\right)$ for the frequency of stems infected with $H$. annosum in a progeny trial of 44-year-old Norway spruce full-sib families. For Scots pine, the estimated $h^{2}$ in open-pollinated families for RotResist was similar to the observed resistance in full-sib families to Dothistroma needle blight $\left(h^{2}=0.38\right)$ [38].

Notably, we detected only very weak undesirable relationships between root rot resistance index and other valuable traits (Table 2), implying potential simultaneous improvement. Besides, the highest estimated correlation (0.28) with BrD might be somewhat exaggerated because of the RotReist construction characteristics. Namely, trees with higher RotResist in the root-rot affected areas tended to face higher mortality around them, thus promoting development of thicker branches because of improved light conditions.

Overall, fungal growth and lesion length in the phloem were not found to correlate with growth and wood quality traits in a study evaluating the incorporation of resistance to H. parviporum in the Norway Spruce Breeding Program [9]. The rather weak, yet significant, positive correlations between family breeding values of RotResist and StVol (Table 2) might be explained by reduced growth among more infected families. In Southern Sweden, assessing relative small sample size, significantly reduced the growth nine years after the first thinning had been detected for trees with even a small proportion of roots being infected; general decline in volume increment was detected as early as three years after the first thinning [39].

\subsection{Selection Methods}

Root rot resistance can be considered a high priority trait alongside $\mathrm{H}$ and $\mathrm{StVol}$ for incorporation into the selection index since it shows notable genetic variance, has high economic impact on timber production value, and does not show an undesirable relationship with growth [18], as also observed for Norway spruce [37]. Unsurprisingly, the reduction of gains in $\mathrm{H}$ and StVol were observed (Table 3) with the inclusion of RotResist as an additional trait into the selection index [18]. Gains in productivity remained positive (6.5-10.4\%), while genetic gains for RotResist increased from ca. $2 \%-5 \%$ to $30 \%-33.7 \%$ (Table 3). Considerable heritability for RotResist (Table 1) might have determined high genetic gain in our case, when assigning equal weight to productivity traits.

Still, higher gains for RotResist and smaller reductions in gains in growth could be achieved by selecting the best (based on selection index) families (backward selection) instead of the best individuals within the best families (Table 3), indicating a higher effectiveness in family selection likely due to sufficiently large environmental deviations affecting the phenotypic variance of the traits [19].

The two-stage selection (S III and S IV) appears to be as effective as single-stage selection (S I and S II), having a small impact on growth and quality traits (Table 3). Under two-stage selection, the aforementioned effectiveness of family selection seems to be retained, providing higher gains for growth traits. However, regarding similar improvement in RotResist in the index and two-stage selection processes, S II should be preferred because little yet improved gains in growth traits were observed for S II compared to S IV (Table 3). 
Overall, the monetary value of forest products must reflect genetic gains for resistance index, and evaluation is necessary regarding whether the added value of RotResist outweighs selection for pure productivity [37]. In our study, we applied equal weights for growth traits and RotResist. Therefore, potential further research should address the optimal economic weight for each trait in the selection index to achieve the greatest economic gain; however, uncertain future economic conditions makes this a difficult task [18]. The loss of merchantable timber because of pathogens is hardly predictable because of numerous site factors affecting the spread of infections $[6,40]$ and reduced resistance to wind damage [6].

Although inclusion of RotResist into the selection criteria indicates substantial improvements in genetic gain, some practical issues may arise regarding the application of the index. In the present study, RotResist was calculated for trees in the sample plots derived from the kriging estimates, which were based on detected rot in cross-sectional wood samples. Such a destructive method involves laborious extra work to include in breeding activities, thereby increasing breeding costs. However, H. annosum may infect Scots pine root systems without any obvious crown symptoms; thus, visual assessment alone may result in the underestimation of disease distribution [7,39,40]. As only Category 2 and 3 trees have been sampled, calculations are based on the minimum size of the pathogen genets. To estimate the exact borders of Heterobasidion genets more accurate sampling would be required (excavated root systems). Still, the observed effectiveness of RotResist may be successfully applied in combination with other, less resource-consuming root rot detection methods at an earlier age, such as non-destructive resistography [41] or assessment during inoculation experiments [15].

\section{Conclusions}

Root rot resistance index appeared to be an effective measure for inclusion in the selection criteria because of its notable genetic variance and lack of undesirable relationship to other growth and quality traits. We suggest the incorporation of the root rot resistance into the conventional selection index of growth traits for family selection, which would considerably improve resistance to root rot causing dieback while maintaining reasonable gains in growth traits. Notwithstanding, further analysis is necessary to adjust economic weights for the traits in the selection index to obtain optimal index performance.

Author Contributions: Conceptualization, R.R.-R. and R.K.; methodology, L.B. and R.R.-R.; software, P.Z. and V.B.; formal analysis, P.Z.; investigation, R.R.-R., R.K., and A.Z.; data curation, V.B.; writing一original draft preparation, R.R.-R. and P.Z.; writing-review and editing, A.Z. and R.K. All authors have read and agreed to the published version of the manuscript.

Funding: This research received no external funding.

Acknowledgments: Study was carried out in Forest competence center (ERDF) project "Technologies for efficient transfer of genetic gain in plant production and forestry" and Latvian state forests (LVM) projects "Tree breeding for selection of superior forest reproductive material", "Investigation of the factors limiting the spread of root rot".

Conflicts of Interest: The authors declare no conflict of interest.

\section{References}

1. Jansson, G.; Hansen, J.K.; Haapanen, M.; Kvaalen, H.; Steffenrem, A. The genetic and economic gains from forest tree breeding programmes in Scandinavia and Finland. Scand. J. For. Res. 2017, 32, 273-286. [CrossRef]

2. Persson, T. Genotype by environment interaction for survival, growth and Cronartium resistance in northern Scots pine. In Genetic Aspects of Adaptation and Mitigation: Forest Health, Wood Quality and Biomass Production, Proceedings of the Book of Abstracts of International Scientific Conference, Riga, Latvia, 3-5 October 2012; Jansons, Ā., Konstantinova, I., Eds.; LSFRI Silava: Salaspils, Latvia, 2012; p. 150.

3. Krakau, U.-K.; Liesebach, M.; Aronen, T.; Lelu-Walter, M.-A.; Schneck, V. Scots Pine (Pinus sylvestris L.); Springer: Dordrecht, Germany, 2013; pp. 267-323. 
4. Neimane, U.; Polmanis, K.; Zaluma, A.; Klavina, D.; Gaitnieks, T.; Jansons, A. Damage caused by Lophodermium needle cast in open-pollinated and control-crossed progeny trials of Scots pine (Pinus sylvestris L.). For. Chron. 2018, 94, 155-161. [CrossRef]

5. Gonthier, P.; Thor, M. Annosus root and butt rots. In Infectious Forest Diseases; Gonthier, P., Nicolotti, G., Eds.; CAB International: Wallingford, UK, 2013; pp. 128-158.

6. Garbelotto, M.; Gonthier, P. Biology, Epidemiology, and Control of Heterobasidion Species Worldwide. Annu. Rev. Phytopathol. 2013, 51, 39-59. [CrossRef] [PubMed]

7. Asiegbu, F.O.; Adomas, A.; Stenlid, J. Conifer root and butt rot caused by Heterobasidion annosum (Fr.) Bref. s.l. Mol. Plant Pathol. 2005, 6, 395-409. [CrossRef] [PubMed]

8. Swedjemark, G.; Stenlid, J.; Karlsson, B. Genetic variation among clones of Picea abies in resistance to growth of Heterobasidion annosum. Silvae Genet. 1998, 46, 369-374.

9. Chen, Z.-Q.; Lundén, K.; Karlsson, B.; Vos, I.; Olson, Å.; Lundqvist, S.-O.; Stenlid, J.; Wu, H.X.; García Gil, M.R.; Elfstrand, M. Early selection for resistance to Heterobasidion parviporum in Norway spruce is not likely to adversely affect growth and wood quality traits in late-age performance. Eur. J. For. Res. 2018, 137, 517-525. [CrossRef]

10. Korshikov, I.I.; Demkovich, A.E. Genetic features of root fungus-resistant scotch pine trees in artificial stands in the steppe zone of Ukraine. Cytol. Genet. 2008, 42, 323-328. [CrossRef]

11. Vasiliauskas, A. Šakninès pinties (Heterobasidion annosum (Fr.) Bref.) paplitimas pušynuose, ıveistuose žemės ùkio naudmenuose, kovos su ja priemonès ir kovos rezultatai [Root rot caused by Heterobasidion annosum in Pinus sylvestris plantations on former agricultural land. Miskininkyste 2001, 2, 42-59.

12. Zaluma, A.; Gailis, A.; Burneviča, N.; Korhonen, K.; Gaitnieks, T. Susceptibility of Picea abies and Pinus sylvestris seedlings of various origins to Heterobasidion annosum and H. parviporum. Proc. Latv. Acad. Sci. 2016, 70, 29-33.

13. Mukrimin, M.; Kovalchuk, A.; Ghimire, R.P.; Kivimäenpää, M.; Sun, H.; Holopainen, J.K.; Asiegbu, F.O. Evaluation of potential genetic and chemical markers for Scots pine tolerance against Heterobasidion annosum infection. Planta 2019, 250, 1881-1895. [CrossRef]

14. Šnepste, I.; Škipars, V.; Krivmane, B.; Brūna, L.; Runǵis, D. Characterization of a Pinus sylvestris thaumatin-like protein gene and determination of antimicrobial activity of the in vitro expressed protein. Tree Genet. Genomes 2018, 14, 58. [CrossRef]

15. Skrøppa, T.; Solheim, H.; Steffenrem, A. Genetic variation, inheritance patterns and parent-offspring relationships after artificial inoculations with Heterobasidion parviporum and Ceratosystis polonica in Norway spruce seed orchards and progeny tests. Silva Fenn. 2015, 49, 1191. [CrossRef]

16. Marčiulynas, A.; Sirgedaitè-Šèžienè, V.; Žemaitis, P.; Baliuckas, V. The Resistance of Scots Pine (Pinus sylvestris L.) Half-sib Families to Heterobasidion annosum. Forests 2019, 10, 287. [CrossRef]

17. Zalıuma, A.; Muižnieks, I.; Gaitnieks, T.; Burneviča, N.; Jansons, Ā.; Jansons, J.; Stenlid, J.; Vasaitis, R. Infection and spread of root rot caused by Heterobasidion spp. in Pinus contorta plantations in Northern Europe: Three case studies. Can. J. For. Res. 2019, 49, 969-977. [CrossRef]

18. White, T.L.; Adams, W.T.; Neale, D.B. Forest Genetics; CABI Publishing: Wallingford, UK, 2007; ISBN 9780851990835.

19. Falconer, D.S.; Mackay, T.F. Introduction to Quantitative Genetics, 4th ed.; Longman Group Ltd.: London, UK, 1996.

20. Hazel, L.N. The Genetic Basis for Constructing Selection Indexes. Genetics 1943, 28, 476-490.

21. Laivinšs, M.; Melecis, V. Bio-geographical interpretation of climate data in Latvia: Multidimensional analysis. Acta Univ. Latv. 2003, 654, 7-22.

22. Harris, I.; Jones, P.D.; Osborn, T.J.; Lister, D.H. Updated high-resolution grids of monthly climatic observations-The CRU TS3.10 Dataset. Int. J. Climatol. 2014, 34, 623-642. [CrossRef]

23. Bušs, K. Meža Ekoloǵija un Tipoloǵija [Forest ecology and typology]; Zinātne: Rīga, Latvia, 1981.

24. Liepa, I. Pieauguma Mācība [Increment Science]; LLU: Jelgava, Latvia, 1996.

25. SAS. SAS/IML 9.3 User's Guide; Sas Institute: Cary, NC, USA, 2011; ISBN 1607649136.

26. Oliver, M.A.; Webster, R. Kriging: A method of interpolation for geographical information systems. Int. J. Geogr. Inf. Syst. 1990, 4, 313-332. [CrossRef]

27. Littell, R.C.; Milliken, G.A.; Stroup, W.W.; Wolfinger, R.D. SAS System for Mixed Models; Sas Institute: Cary, NC, USA, 1996. 
28. Littel, R.C.; Milliken, G.A.; Stroup, W.W.; Wolfinger, R.D.; Schabenberger, O. SAS for Mixed Models, 2nd ed.; Sas Institute: Cary, NC, USA, 2006; Volume 816.

29. Dickerson, G.E. Techniques for research in quantitative animal genetics. In Techniques and Procedures in Animal Science Research; American Society of Animal Production: Albany, NY, USA, 1969; pp. 36-79.

30. Baumanis, I.; Jansons, A.; Neimane, U. Priede: Selekcija, Genētika un Sēklkopība Latvijā [Scots Pine: Breeding, Genetics and Seed Orchard Management]; Daugavpils Universitātes Akadēmiskais apgāds "Saule": Daugavpils, Latvia, 2014.

31. Evans, J.D. Straightforward Statistics for the Behavioral Sciences; Thomson Brooks/Cole Publishing Co.: Belmont, CA, USA, 1996.

32. Swedjemark, G.; Karlsson, B. Genotypic variation in susceptibility following artificial Heterobasidion annosum inoculation of Picea abies clones in a 17-year-old field test. Scand. J. For. Res. 2004, 19, 103-111. [CrossRef]

33. Swedjemark, G.; Karlsson, B. Variation in incidence and genetic impact on natural infection of Heterobasidion annosum in Picea abies (L.) Karst. in genetic trials in south Sweden. For. Ecol. Manag. 2004, 203, $135-145$. [CrossRef]

34. Wellendorf, H.; Thomsen, I.M. Genetic variation in resistance against Heterobasidion annosum (Fr.) bref. in Picea abies (L.) karst. expressed after inoculation of neighboring stumps. Silvae Genet. 2008, 57, 312-324. [CrossRef]

35. Arnerup, J.; Swedjemark, G.; Elfstrand, M.; Karlsson, B.; Stenlid, J. Variation in growth of Heterobasidion parviporum in a full-sib family of Picea abies. Scand. J. For. Res. 2010, 25, 106-110. [CrossRef]

36. Skrøppa, T.; Solheim, H.; Hietala, A. Variation in phloem resistance of Norway spruce clones and families to Heterobasidion parviporum and Ceratocystis polonica and its relationship to phenology and growth traits. Scand. J. For. Res. 2015, 30, 103-111. [CrossRef]

37. Steffenrem, A.; Solheim, H.; Skrøppa, T. Genetic parameters for wood quality traits and resistance to the pathogens Heterobasidion parviporum and Endoconidiophora polonica in a Norway spruce breeding population. Eur. J. For. Res. 2016, 135, 815-825. [CrossRef]

38. Perry, A.; Wachowiak, W.; Brown, A.V.; Ennos, R.A.; Cottrell, J.E.; Cavers, S. Substantial heritable variation for susceptibility to Dothistroma septosporum within populations of native British Scots pine (Pinus sylvestris). Plant Pathol. 2016, 65, 987-996. [CrossRef]

39. Wang, L.; Zhang, J.; Drobyshev, I.; Cleary, M.; Rönnberg, J. Incidence and impact of root infection by Heterobasidion spp., and the justification for preventative silvicultural measures on Scots pine trees: A case study in southern Sweden. For. Ecol. Manag. 2014, 315, 153-159. [CrossRef]

40. Rönnberg, J.; Petrylaite, E.; Nilsson, G.; Pratt, J. Two studies to assess the risk to Pinus sylvestris from Heterobasidion spp. in southern Sweden. Scand. J. For. Res. 2006, 21, 405-413. [CrossRef]

41. Allikmäe, E.; Laarmann, D.; Korjus, H. Vitality assessment of visually healthy trees in Estonia. Forests 2017, 8, 223. [CrossRef]

(C) 2019 by the authors. Licensee MDPI, Basel, Switzerland. This article is an open access article distributed under the terms and conditions of the Creative Commons Attribution (CC BY) license (http://creativecommons.org/licenses/by/4.0/). 